\title{
Structural evolution of the Ikerasak area, Umanak district, central West Greenland
}

\section{John Grocott}

The 1980 season was the last of the three seasons allocated for the mapping of the 1:100000 sheet 70 V. 2 Nord-Agpat (for background and references see Pulvertaft, 1979). The most important area that remained to be mapped in 1980 consisted of the islands Ikerasak and Talerua, which were known from the 1965 reconnaissance by T. C. R. Pulvertaft to have a structural style somewhat different from that of the northern part of the sheet area where low dips are prevalent. The author was invited to join the team of geologists from Copenhagen University responsible for the Agpat sheet to map these islands and the mainland peninsula of Akuliaruserssuaq to the south-east (fig. 11).

The geology of Ikerasak, Talerua and Akuliaruserssuaq can best be described with reference to the structural domains shown in fig. 11. The geological history is summarised in Table 2. Some important aspects of the chronology are highlighted in the following paragraphs.

The dominant rock type is biotite gneiss, containing many more or less continuous, amphibolite-dominated supracrustal units. The rocks are in upper amphibolite facies with the exception of a belt of hypersthene-bearing gneiss in western Ikerasak (fig. 11). This is the only occurrence of granulite facies rocks that has been reported from the Umanak area.

The contacts between gneiss and supracrustals are concordant and are usually loci of high strain with mylonitic microstructures. Occasionally contacts are transitional through a belt of agmatite. A few amphibolites end along the strike in a belt of agmatite. At such places, banding in the gneisses cuts across folded banding in amphibolite inclusions, suggesting that at least two phases of deformation occurred in the supracrustal units before they were incorporated in their present position in the gneisses. The continuity of the amphibolite horizons and the frequent occurrence of mylonite at contacts, suggests that supracrustals and gneisses were tectonically interleaved; this tectonic interleaving may of course have been superimposed on a primary intrusive sheeting of granite/gneiss in supracrustals. Banding in the gneisses is believed to have been developed primarily during the tectonic interleaving.

The amphibolite horizons and the gneiss banding are deformed by the earliest major fold phase $F_{1}$ (Table 2). An isoclinal synform of this age occurs in western Ikerasak, where later phases of deformation are weak, and folds the belt of hypersthene gneiss. This granulite facies gneiss is weakly deformed, showing only nebulous banding, and it is retrogressed on either side as deformation increases.

Several relatively steep planar zones of high deformation are shown on fig. 11. These boundaries are drawn at the limits of intensely deformed flaggy gneisses. The main south-dipping zone is referred to in this account as the Ikerasak shear zone, and the north-dipping shear zone as the Talerua shear zone (fig. 11). All linear structures in both shear zones plunge gently west or east. Between the two shear zones is a belt of hornblende dioritic to hornblende granodioritic gneiss containing weak $L$ tectonite fabrics and fold interference patterns where it is more strongly layered. These patterns result from interference of coaxial fold trains where folds with north-dipping axial surfaces are superimposed on 


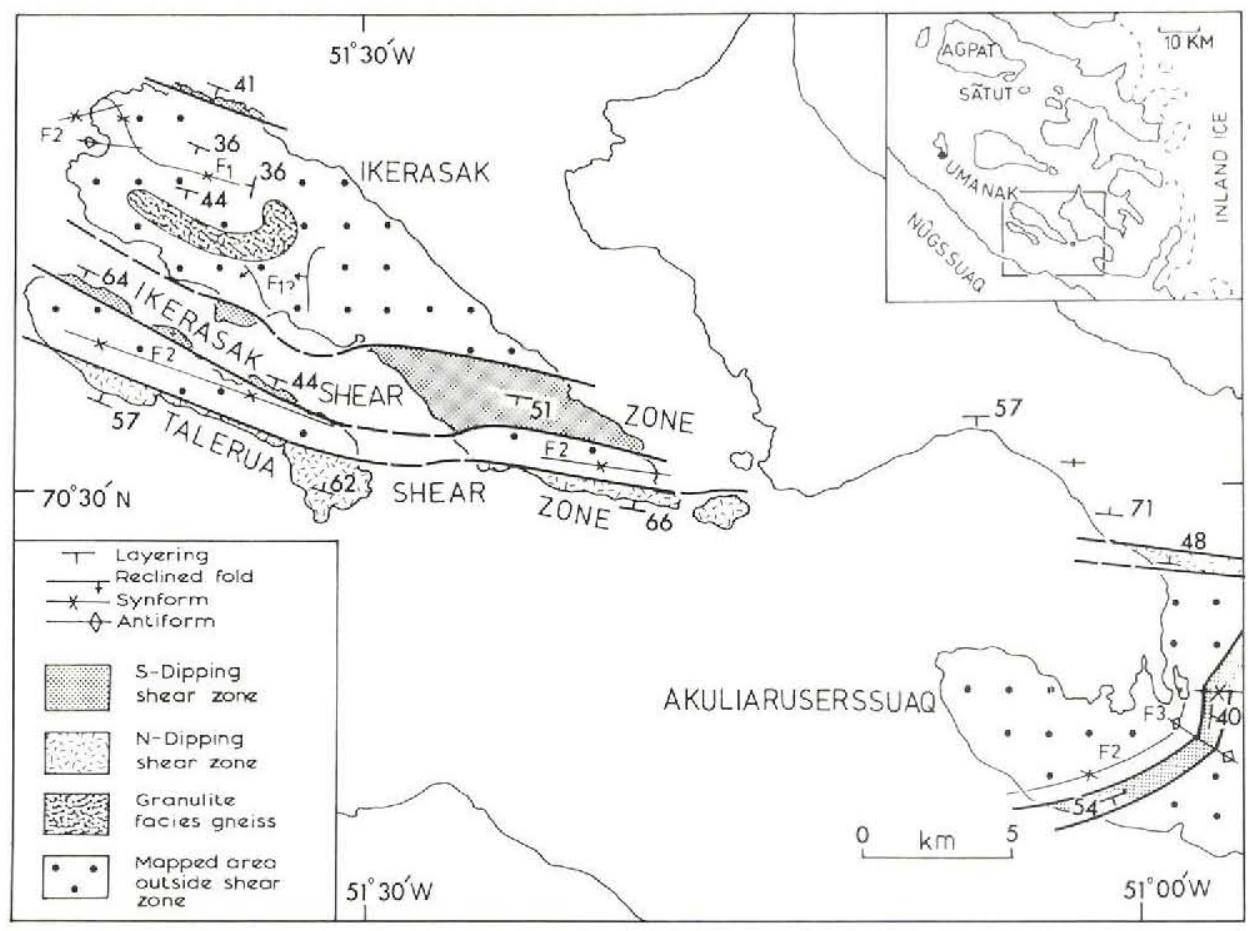

Fig. 11. Map of the Ikerasak area showing the distribution of structural domains.

folds with south-dipping axial surfaces. These folds are believed to be the same age as the north-dipping and south-dipping shear zones, respectively. The largest scale structures in this area of relatively low deformation are folds overturned northwards with axial traces slightly oblique to the trend of strongly deformed rocks in the shear zone (fig. 11). North of the Ikerasak shear zone, and east of the belt of granulite facies gneisses, a similar area of coaxial interference patterns, which also involves large scale isoclines, occurs (fig. 11).

South-dipping shear zones are deformed by folds with north-dipping axial planes related to the Talerua shear zone. This occurs on a large scale on Akuliaruserssuaq (fig. 11), and east of the mapped area aerial photographs suggest that the south-dipping shear zone on this peninsula is deformed into the eastwards extension of the Talerua shear zone.

Discordant basic intrusions of widely varying thickness and degree of recrystallisation occur at scattered localities throughout the area. They post-date the small segment of a shear zone exposed on north Ikerasak and the $F_{1}$ isoclines. Farther south a $200 \mathrm{~m}$ thick, recrystallised but largely undeformed example occurs near the abandoned settlement of Ümánatsiaq. Here much of the deformation in the contact gneisses, which varies from extreme to weak over less than $20 \mathrm{~m}$, may be synplutonic. This intrusion appears to cut across folds with south-dipping axial planes related to the Ikerasak shear zone. However, farther east related folds deform narrow, still discordant, though thoroughly amphibolitised dykes. In the Talerua shear zone locally discordant basic dykes are usually completely amphibolitised, but 
Table 2. Sequence of events described from the Ikerasak area

1a At least two phases of deformation in supracrustal rocks.

1b Primary intrusive sheeting of gneiss precursors into the supracrustal rocks.

1c Granulite facies metamorphism.

2 Tectonic interleaving of supracrustal units and gneisses under amphibolite facies conditions. Mylonites at contacts.

3 Large scale isoclinal folding $F_{1}$ (originally flat-lying axial planes).

4 Formation of the high deformation zone on north-west Ikerasak.

5 South-dipping belts with constant strike (e.g. Ikerasak shear zone) and related folds $F_{2}$. Upper amphibolite facies.

6 Emplacement of basic intrusions towards the close of event 5 ?.

7 North-dipping steep belt with constant strike (Talerua shear zone) and related folds $F_{3}$. Basic dykes synkinematic with respect to this deformation?

8 Unmetamorphosed and undeformed WNW-trending basic dykes.

9 Vertical faults. (a) NNW dextral, maximum horizontal displacement $50 \mathrm{~m}$. (b) NNE sinistral, maximum horizontal displacement $500 \mathrm{~m}$. Very occasional pseudotachylite. Retrogression to greenschist facies along fault zones.

occasionally in the central portion of these intrusions sub-ophitic texture occurs even where the country rocks are exceptionally platey. Shape variation of these intrusions can be extreme, but quite large discordance may be preserved in the thinnest of necks suggesting that some of the shape variation may be primary, and that, in turn, suggests synkinematic emplacement. Thus while a few dykes are earlier than at least some deformation in the Ikerasak shear zone, others could be synkinematic with respect to the Talerua shear zone.

At a much later stage in the geological history the area was cut by unmetamorphosed and undeformed WNW-trending basic dykes and two sets of faults (Table 2).

\section{Reference}

Pulvertaft, T. C. R. 1979: Mapping in the Umanak district, central West Greenland. Rapp. Grønlands geol. Unders. 95, 27-30.

Geologisch Instituut der Universiteit van Amsterdam, Nieuwe Prinsengracht 130, Amsterdam, Holland. 